\title{
Exploring the links between culture and innovation in micro firms: cultural dimensions, social mechanisms and outcomes
}

\section{Madelon van Oostrom \& Manuel Fernández-Esquinas}

To cite this article: Madelon van Oostrom \& Manuel Fernández-Esquinas (2017) Exploring the links between culture and innovation in micro firms: cultural dimensions, social mechanisms and outcomes, European Planning Studies, 25:11, 1932-1953, DOI: 10.1080/09654313.2017.1355355

To link to this article: https://doi.org/10.1080/09654313.2017.1355355

\section{冓 Published online: 01 Aug 2017.}

Submit your article to this journal $\widetilde{ }$

Џll Article views: 338

Q View related articles $\sqsubset$

View Crossmark data ¿

Citing articles: 1 View citing articles $\square$ 


\title{
Exploring the links between culture and innovation in micro firms: cultural dimensions, social mechanisms and outcomes
}

\author{
Madelon van Oostrom (1D) ${ }^{a, b}$ and Manuel Fernández-Esquinas ${ }^{c}$ \\ ${ }^{\mathrm{a} H a n z e}$ University of Applied Sciences, Groningen, The Netherlands; ${ }^{\mathrm{b}}$ Tenerife Science and Technology Park, \\ Santa Cruz de Tenerife, Spain; 'CSIC, Institute for Advances Social Studies, Córdoba, Spain
}

\begin{abstract}
This article analyses the role of cultural components in the innovation processes of micro firms. The article develops an analytical and operational approach to the notion of culture of innovation departing from conceptual contributions from cultural and economic sociology. This framework is used in a study of micro firms in the Canary Islands (Spain). A survey, a group of open-ended interviews and in-depth case studies have been used to identify and explain the social and cultural mechanisms that make up the culture of innovation of small firms and shape their open innovation strategies. The results highlight the importance of firms' knowledge base in the configuration of different innovation behaviours. The findings also help to explore the relationship between homogeneous and pluralistic conceptions of the culture of innovation.
\end{abstract}

ARTICLE HISTORY

Received 28 April 2017

Revised 7 July 2017

Accepted 11 July 2017

\section{KEYWORDS}

Innovation; culture; micro firms; institutions; open innovation; sociology of innovation

\section{Introduction}

This article explores the innovation processes in small and medium-sized firms (SMEs) and micro firms in regional innovation systems. Its main goal is to analyse the social and cultural mechanisms through which these firms carry out innovation in the disadvantaged environments of the so-called peripheral regions. Innovation dynamics of firms and underlying knowledge production processes are considered of crucial importance for regional development. However, the capacities to undertake innovation are very context-dependent on both the characteristics of the firms and the configuration of the regional environment, especially by actors and institutions that shape innovation (Edquist, 2005). An important barrier to innovation is related to the profile of firms present in a region. Firm innovation is shaped by productive specialization, internal structure and capacities of firms, and by their external links. Specialized research has widely evidenced that innovation is connected to high-tech sectors, to firms with specialized units and trained personnel able to absorb knowledge, and to firms with fluent relationships with suppliers, clients and knowledge providers (Cohen \& Levinthal, 1990; van der Panne, van Beers, \& Kleinknecht, 2003). These traits are closely associated with bigger firms. With the exception of the specific profile of small science and technology firms 
(mainly start-ups and spin-offs), seldom are they found in firms located in most regions (Tether, Mina, Consoli, \& Gagliaardi, 2005), especially in peripheral regions characterized by a lack of industrial agglomeration and an overwhelming presence of very small or micro firms. As a result, these firms are beyond the scope of innovation studies (Freel, 2005)

Some important frameworks have started paying attention to sources of innovation in the network of diversified firms of peripheral regions, including SMEs and micro firms not directly linked to R\&D. The innovation system approach, especially at the regional level (Cooke, Gomez Uranga, \& Etxebarria, 1997), is perhaps one of the more pioneering endeavours focusing on the complex array of elements that help to identify endogenous sources of innovation in the configuration of local firms and other relevant actors in the system. Other complementary frameworks consider firms' potential from a microlevel perspective, such as the open innovation approach, and pay special attention to their capacities and strategies for exchanging and using sources of knowledge available in the environment (Chesbrough, 2012).

What these frameworks have in common is the growing importance attributed to institutional dimensions, such as laws, policies and regulations, capacities and education. Increasingly, they have been paying special attention to cultural dimensions. Regional innovation studies are considering that culture is important for firm innovation, because values, informal norms and cognitive frameworks shape the capacity to act and to establish links with key external actors for innovation (Asheim \& Isaksen, 2002; James, 2005; Trippl \& Toedtling, 2008). The influence of cultural dimensions on innovation performance has also gained interest in organizational and management theories (Jaruzelski, Loehr, \& Holman, 2011). In the case of SMEs, there has also been a reaction to the mainstream innovation literature that ignores the so-called 'softer' sociocultural elements, sometimes considering them as a 'residual' explanation of innovation capacities and performance (James, 2005).

However, there are some important gaps in the innovation literature regarding the role of cultural dimensions, especially in micro firms. In general, there is a lack of conceptual precision when referring to cultural factors. They are often treated as a part of the complex 'institutional thickness' (Amin \& Thrift, 1995), while the observation of institutional mechanisms goes unnoticed. A conceptual problem also arises for empirical research because of the blurred meanings assigned to frequently used concepts, such as the different kinds of institutional components referring to norms, values and cognitive frameworks, and their relationship with other important explanatory mechanisms, such as social capital and innovation networks (Pilon \& DeBresson, 2003). These mechanisms are especially influential in micro firms because the strategies, relationships and performance of these firms are directly mediated by the cultural traits of the owner and core workers.

In this article, we observe the innovation dynamics of micro firms informed by a crossfertilization of different analytical approaches that pay attention to the influential role of culture. Theoretical contributions from economic and cultural sociology are employed as a useful complement to innovation studies, together with insights from the regional innovation system approach and open innovation frameworks. For this purpose, we present empirical findings on innovation dynamics in the Canary Islands (Spain). This is an outermost region characterized by a service economy and low innovation performance that can be considered a representative example of a peripheral region where the innovative 
dynamics of micro firms are an essential component of the regional innovation system. The conceptual exercise is used to inform empirical research based mainly on qualitative interviews and case studies that help to explain the richness and complexity of innovation dynamics in micro firms.

The article is structured as follows: after the introduction, Section 2 reviews the key conceptual frameworks and provides some conceptual clarifications. Section 3 establishes an operational definition of the culture of innovation and its main dimensions. Section 4 describes case study methodology and design. Section 5 discusses the main results. Finally, some implications of interest to policymakers and managers are summarized in the conclusions.

\section{Background}

\subsection{Culture and innovation in SMEs: issues and gaps in current literature}

Innovation is generally understood as an interactive process of value creation and problem solving based on both tacit (experiences, ideas and skills) and explicit or codified (technology) knowledge. It refers, on the one hand, to new or improved products, services, processes and methods, some of which are driven by technology and, on the other, to change in organizational procedures. When examining innovation, it is helpful to distinguish explanations at different levels of analysis. For the purpose of this article, it is useful to look at the systemic approach that explains innovation at the meso level of an innovation system and the open innovation approach that studies how firms innovate mainly at the micro level. Both share important consensus about the nature of innovation (in opposition to the linear model that perceives innovation as an orderly outcome of earlier research and development processes) and the interactive and social understanding of innovation processes (Bessant \& Tidd, 2007; Drucker, 2014; Edquist, 2005; Fagerberg \& Verspagen, 2009; Lundvall \& Borrás, 1997; Manley, 2003).

The innovation system approach, whether national (Nelson \& Winter, 1982), regional (Asheim \& Isaksen, 2002; Cooke et al., 1997), local (Fernández-Esquinas \& Pinto, 2014) or sectorial (Malerba, 2005), regards innovation as the outcome of a systematic process in order to explain the generation and use of the technology available in a certain environment. Innovation is considered as a dynamic and social process based on interactive learning processes between the system's key agents and their interactions: knowledge producers (universities and educational establishments), knowledge transfer regulators (governmental agencies), interface organizations (knowledge transfer and innovation centres), and knowledge exploiters and diffusers (firms). Institutions, such as laws and norms, are considered crucial elements since 'they shape (and are shaped by) the actions of the organizations and the relations between them' (Edquist, 2001, p. 3). Innovation systems are thus conceived as the set of organizations and institutions that generate and shape innovation through both collaborative and competitive interactions.

Moreover, open innovation perspectives pay special attention to both the strategies and capacities to exchange information as a key source of firm innovation (Chesbrough, 2012). The value of incorporating information from outside the firm has been highlighted by earlier business innovation literature with notions such as absorptive capacity or permeability that stress the ability to transform external information into internal value 
(Cohen \& Levinthal, 1990). In addition to contributions associated with open innovation, such as open business models and open innovation for service development (Chesbrough, 2012), other authors highlight the importance of user and consumer feedback (von Hippel, 2005) for firms' innovation performance.

The assumptions of these approaches are especially important for peripheral regions. Peripheral regions are afflicted by various structural problems, for example, lack of capabilities, poor support infrastructure, lack of critical mass and difficult access to markets and technological knowledge (Fernández-Esquinas, Pinto, Yruela, \& Pereira, 2016; Trippl \& Toedtling, 2008). Peripheral regions are also shaped by specific social, economic and political mechanisms that determine their current situation in the knowledge economy. In these regions, interactions and capacities to access external sources of knowledge and other resources are crucial for SMEs and micro firms, which compose the largest portion of all businesses. Intangible elements, such as cultural values and cognitive repertoires, can also be an important explanatory factor for innovation dynamics. The main reason, as we will explain below, is that these elements are especially influential in the innovation process of these firms.

Although the above approaches acknowledge the social and interactive nature of innovation, they seldom encompass cultural analysis or introduce elements that facilitate the comprehension of cultural aspects. They recognize the influence of institutions, social capital, norms, values, abilities and attitudes, yet there is currently no comprehensive definition of the culture of innovation as a basic and operative element of institutional analysis in innovation studies. One of the reasons may be attributed to the separation of theoretical domains into different strands of social sciences. Innovation studies barely examine innovation through the analytical lens of other streams of research that focus specifically on institutional components. Moreover, institutional approaches that pay attention to culture have not considered firm innovation processes as strategic research sites; hence the need for a deeper understanding of the cultural elements that foster innovation capacity and performance.

\subsection{Some conceptual problems and clarifications}

The social nature of innovation situates culture in an important position from which to explain innovation processes. Economic activities can be shaped by shared beliefs, perceptions, attitudes and abilities held by the majority of a social group and put in practice through interaction, and interpersonal and social negotiation (Sackmann, 1997; Zelizer, 2010). In particular, the cognitive base that refers to complex rule-like structures can be influential for firm innovation, because these structures constitute strategic resources (DiMaggio, 1997).

A sociological use of the term 'institution' as a system of social rules helps clarify the role of cultural elements in innovation, since cultural aspects are commonly understood as parts of the institutional domain. The sociological lens complements the systemic approach that highlights the more formal and visible aspects of an innovation system, and, as such, contributes to expand the set of observations relating to the institutional components (Casper \& Van Waarden, 2005). It involves the study of the beliefs and values of the key actors involved in innovation, together with norms and cognitive skills, integrated with other influential factors that shape innovation. 
To that end, the work of Portes (2013) is especially useful for conceptual clarification. The observation of complex social phenomena not easily apprehensible at surface level reveals an important differentiation between meta-theoretical principles (the distinctive cognitive lens through which a particular field sees social phenomena and privilege areas or reality), explanatory mechanisms (a set of ideas about the functioning of social reality used as 'tool kits' to understand and clarify concrete events) and strategic sites of enquiry (locations for research, where observations of social dynamics are present and arguments can be tested). This conceptual differentiation is especially useful when analysing innovation processes.

In the case of innovation in SMEs and micro firms, a meta-theoretical principle shared by innovation studies is to consider all economic actions as embedded in systems of social relations that cannot be restricted to the individual interests of actors (Granovetter, 1985); a cognitive lens which is essentially different from the meta-theoretical principle stated by the utilitarian approach prevailing in mainstream economics. Second, cultural elements are considered to be a group of explanatory mechanisms that may shape innovation processes. They require detailed empirical observation, combined with other explanatory mechanisms usually assumed to be important for innovation, such as the role of social capital or the relationship with knowledge providers. And third, SMEs and micro firms provide a strategic research site for observing this explanatory mechanism, because they contain social and economic characteristics that make the functioning of the cultural elements especially relevant to the explanation of innovation dynamics.

Another key differentiation, also from Portes (2013), is bound up with the meaning attributed to the notion of 'institutions' and their relationship with culture. Portes departs from the classical analytical differentiation in mainstream sociological theory which states that social life can be examined according to two dimensions: the social structural domain (formed of real persons organized in economic and social hierarchies of some kind) and the cultural domain (formed by the symbolic elements of social life crucial for human interaction, mutual understanding and order). This separation is purely analytical, because in real life humans only exist in physical reality. However, it does aid observation of the motivations behind individuals' actions and the consequences of those actions; it also aids distinction between layers of social structure and culture.

Both dimensions are composed of diverse elements that can be analytically defined: from surface phenomena easily perceivable in everyday life to the most profound elements in the constitution of society. In particular, the social structure refers to the position of individuals in society, distributed in hierarchies according to their access to scarce resources, enabled by social relations and individuals' social capital. The most visible outcome of a social structure is a group of organizations present in a given area of activity. Values, norms, roles, cognitive repertoires, roles and institutions form the cultural structure. Values represent a more profound level, are sometimes expressed in norms and are enacted through individual roles. The most tangible outcomes of the cultural structure are institutions, a concept restricted to the symbolic part of organizations and defined as sets of rules that govern and shape the relations between role occupants in organizations (Portes, 2013). Institutions emerge when people manage to bring cognitive and normative elements into practice. Institutions are supported by shared systems of rules and behaviour patterns that limit the ability of actors to act and privilege certain groups endowed with influence and legitimacy (DiMaggio \& Powell, 1983). In sum, this scheme helps to 
analytically identify a sphere of values, cognitive frameworks and accumulated knowledge (culture), and a sphere of interests and social positions, supported by different amounts of resources and power (social structure).

Conceived in this way, a social and a cultural structure of an innovation system can be suggested (Fernández-Esquinas, 2012). The social structure is defined in terms of the group of organizations intervening in knowledge production and utilization, and their interactions or networks of relationships. From this perspective, the social network of any key actor in the system, such as the firm, is conditioned by unequal access to resources (codified knowledge, financial capital, relationships, etc.). The cultural structure is formed by values, skills, norms and institutions, and provides the symbolic base that arranges social interactions. It contains a toolkit of elements that may function as assets: expert knowledge, behaviour, roles, manners, skills, etc. These cultural elements are also identified in cultural sociology as cultural capital or repertoires (Bourdieu, 1986; Swidler, 1986; Zelizer, 2010).

Social capital arises at the intersection of these domains, as it relates both to social networks and their facilitating access to certain resources, and to the value of trust associated with consolidated social relationships. Weak ties between actors with few interactions, built with just enough trust to transmit non-redundant information, are considered essential for innovation, whereas strong ties between actors with densely embedded interactions are supposed to involve conformity and risk avoidance (Granovetter, 1973; Ruef, 2002). These are fundamental elements of the concept of culture of innovation that will be discussed in the analysis. But first, the next section describes the main operational dimensions for observing innovation dynamics in SMEs.

\section{Towards an integrative framework for studying the links between culture and innovation}

\subsection{The complexity of cultural analysis and its implication for innovation studies}

The study of culture has been a complex endeavour for social sciences. The origins of cultural research lie in anthropology and sociology, and it has traditionally been analysed from two perspectives, each with its own epistemic and methodological lens: the etic and emic approaches. A key issue of the discussion is the way in which culture is best studied: through the methodological lens that privileges the insider (emic) or the outsider (etic). Anthropologists mostly employ emic perspectives and ethnographic tools. The etic perspective is more common for social psychologists and management scholars, who often approach culture through external evaluation processes. Quantitative research methods are common in this approach, although many organizational scholars also rely on qualitative methods and context-specific observations.

The complexity of cultural analysis is also present in the study of innovation. Innovation has a paradoxical nature because of the combination of dynamism and social change, and the stability needed to produce a valuable outcome. This dual nature is related to etic and emic approaches and leads to different visions about the analytical tools for studying homogeneity or heterogeneity. Some authors focus on aspects of culture that remain relatively stable, because shared beliefs and values are sustained by the fundamental assumptions that provide order to society. Their methodologies tend 
to capture a rather homogeneous view of culture, which is common in comparative crosscultural research that usually employs statistical surveys (Hofstede, 1980; Schwartz, 1994). Cross-cultural research that follows an etic approach typically investigates different responses to similar situations and problems in different countries (or organizations), finding different cultural traits in different social domains that help establish hierarchies of human values on a general scale.

The other conception of culture recognizes a greater diversity and internal incoherence between the individuals and groups that share cultures or subcultures (DiMaggio, 1997). This perspective involves a more heterogeneous vision that aligns with the emic approach. It conceives culture as the collective construction of social reality through cognitive processes that give meaning to social situations in which individuals negotiate the meanings attributed to actions (Sackmann, 1997). Multiplicity implies more complexity in the empirical observation and understanding of culture. The methodologies of this perspective tend to stress specificity in contrast to universality. They also imply a context-related nature of culture when individuals simultaneously belong to different social groups and assume different roles.

The cultural aspects of innovation can thus be examined at multiple levels of analysis: individuals (groups or aggregates), organizations, organizational fields (innovation systems, sectors or clusters), regions or countries. Actors may belong to a multiplicity of cultural communities (Sackmann, 1997) with different cultural identities. They participate in innovation processes at an individual or group level when they co-create, consume and diffuse innovations, but also in a wider social context as members of work teams, professional communities or organizations. In consequence, in order to study the influence of certain cultural aspects on innovation, it becomes necessary to examine the dominating culture in each of them, especially where innovation has major implications.

\subsection{Definition of the culture of innovation: universality or specificity?}

We depart from a cognitive perspective of culture. From a methodological point of view, however, it is useful to combine it with the strategy of etic approaches by considering a series of parameters that reflect diversified factors regarding innovation. This helps to explain the different responses of actors to common situations, for instance, in firms. It is useful to observe a general set of aspects of culture when considering key components that shape diversity. In this respect, we follow some authors (Jucevicius, 2010) who argue in favour of the idea of a plurality of cultures of innovation, since innovative environments can be highly specific in each particular cultural context, due to growing global complexity.

Different combinations of dimensions associated with culture and their influence on innovation should be considered. The culture of innovation is defined as the set of shared beliefs, values, attitudes and abilities that favour innovation processes. These are considered altogether as toolkits (Swidler, 1986) or repertoires that combine learning with cooperation (Jucevicius, 2007). From this viewpoint, there is not only one specific culture of innovation, but different types of cultures that may shape innovation in different contexts. A culture of innovation can be understood as the combination of a set of symbolic elements related to learning, in order to respond to the changing nature of 'creative destruction', and another set related to cooperation, which responds to the more stable 
nature of patterns of interaction between actors that have evolved over a period of time and are usually based on mutual trust (Jucevicius, 2007).

This interpretation of cultural elements is important for SMEs and micro firms. Because they are small, they seldom have internal departments. They have few written rules, codified protocols or organizational procedures. Their strength lies in the owner's personal characteristics, such as flexibility and motivation (Vossen, 1998). More often than not, owners are also leaders and the main workers of the firm (Benito Hernández, Platero Jaime, \& Rodríguez Duarte, 2012). Their cognitive frameworks, values, beliefs and shared meaning are especially important for defining and developing innovative activities. In consequence, the behaviour of a small business is closely connected to that of its owner or manager (Bosma, van Praag, Thurik, \& de Wit, 2004). These circumstances also shape interactions with external agents in the regional context, as well as strategies for learning and investing in new knowledge. The main assumption is that these traits are crucial for adapting to change and for adopting new productive processes.

\subsection{Key dimension of the culture of innovation}

In order to identify both the general and specific elements that differentiate the culture of innovation, we developed an analytic exercise - summarized in Table 1 - based on an extensive review of the literature. ${ }^{1}$ Six main dimensions have been identified as the leading cultural determinants of innovation. Understood as core values and associated skills and practices (Portes, 2013), they are interpreted as hypothetical mechanisms that mobilize capacities or resources which may affect the innovation performance of the firm. Column 1 summarizes the main mechanisms for each dimension. Columns 4 and 5 include the associated values and skills. The rationale for each dimension is as follows:

Dimension 1: Openness to change and novelty. This set of values and skills is expected to help people and organizations adapt to new, uncertain situations that are potentially conflictive. It also facilitates absorption of external information. Associated values are curiosity and interest in experimenting new things with skills, as well as adaptability, flexibility and mobility.

Dimension 2: Willingness to cooperate and share information and knowledge. It refers to the effects of collaboration and exchange of internal and external knowledge on the process of creating new combinations of knowledge. The collaborative relationships between actors inside and outside the firm help to enhance the firm's absorptive capacity. Trust is an important associated value necessary for the creation of social capital. It implies autonomy and recognition in collaborating parties.

Dimension 3: Tolerance of diversity and critical, creative thinking. This set of values is expected to facilitate problem solving through creative processes. Educational, economic, generational, ethnic and gender differences may contribute to problem solving with more creative, divergent and critical outcomes, through different points of view. Associated values such as originality, freedom and imagination may facilitate openness to different views and the acceptance of conflictive points of view.

Dimension 4: Lifelong and collective learning mindset. Emphasis on lifelong learning is expected to enable knowledge absorption and transfer as a continuous process of adaptation to change. Organizational learning processes rely on curiosity and willingness to learn with skills such as learning capacity and open communication. 


\begin{tabular}{|c|c|c|c|c|c|c|}
\hline \multirow[b]{2}{*}{ Dimensions } & \multirow[b]{2}{*}{ Rationale } & \multirow{2}{*}{$\begin{array}{c}\text { Homogeneous } \\
\text { perspective of innovation } \\
\text { culture } \\
\text { Main question: What? }\end{array}$} & $\begin{array}{l}\text { Pluralistic perspective } \\
\text { of innovation culture }\end{array}$ & \multirow[b]{2}{*}{ Values } & \multirow[b]{2}{*}{ Skills (repertoire) } & \multirow[b]{2}{*}{ References } \\
\hline & & & $\begin{array}{l}\text { Main question: How? } \\
\text { What kind of? }\end{array}$ & & & \\
\hline $\begin{array}{l}\text { 1. Openness to } \\
\text { change and novelty }\end{array}$ & $\begin{array}{l}\text { Openness to change and novelty } \\
\text { aids adaptation to new, } \\
\text { potentially uncertain and } \\
\text { conflictive situations, as well as } \\
\text { absorption of external } \\
\text { information }\end{array}$ & $\begin{array}{l}\text { To what extent is change } \\
\text { embraced? To what } \\
\text { extent is attention } \\
\text { being paid to novelty? }\end{array}$ & $\begin{array}{l}\text { How is change faced? } \\
\text { Are changes } \\
\text { accepted easily? } \\
\text { Which changes are } \\
\text { accepted and which } \\
\text { are not? }\end{array}$ & $\begin{array}{l}\text { Curiosity; } \\
\text { innocence; love } \\
\text { for adventure }\end{array}$ & $\begin{array}{l}\text { Adaptability; flexibility and } \\
\text { mobility }\end{array}$ & $\begin{array}{l}\text { Chesbrough (2003); } \\
\text { Godin (2008) }\end{array}$ \\
\hline $\begin{array}{l}\text { 2. Willingness to } \\
\text { cooperate and } \\
\text { share information } \\
\text { and/or knowledge }\end{array}$ & $\begin{array}{l}\text { Willingness to cooperate and } \\
\text { share information and } \\
\text { knowledge internally or } \\
\text { externally originates } \\
\text { innovation processes through } \\
\text { co-creation or crowdsourcing }\end{array}$ & $\begin{array}{l}\text { To what extent is } \\
\text { information absorbed? } \\
\text { What are the levels of } \\
\text { trust? To what extent } \\
\text { does cooperation exist? }\end{array}$ & $\begin{array}{l}\text { How are cooperation } \\
\text { experiences defined? } \\
\text { How are incentives or } \\
\text { obstacles identified? }\end{array}$ & $\begin{array}{l}\text { Trust; freedom; peer } \\
\text { recognition; } \\
\text { sustainability; } \\
\text { reputation; } \\
\text { openness }\end{array}$ & $\begin{array}{l}\text { Knowledge absorption; } \\
\text { ability to cooperate; } \\
\text { communication skills; } \\
\text { sociability; social capital }\end{array}$ & $\begin{array}{l}\text { Cohen and Levinthal, } \\
\text { (1990); Gray, (2006); } \\
\text { Himanen, (2001); } \\
\text { Werker, Ooms, and } \\
\text { Caniëls, (2014) }\end{array}$ \\
\hline $\begin{array}{l}\text { 3. Tolerance of } \\
\text { diversity and } \\
\text { critical, creative } \\
\text { thinking }\end{array}$ & $\begin{array}{l}\text { Tolerance of diversity and } \\
\text { critical, creative thinking } \\
\text { facilitates problem solving } \\
\text { through creative processes } \\
\text { such as design thinking }\end{array}$ & $\begin{array}{l}\text { To what extent is } \\
\text { diversity appreciated? } \\
\text { To what extent is } \\
\text { creativity boosted and } \\
\text { are critics being } \\
\text { accepted? }\end{array}$ & $\begin{array}{l}\text { What kind of diversity } \\
\text { prevails? How are } \\
\text { critics being } \\
\text { managed? How are } \\
\text { creative processes } \\
\text { boosted? }\end{array}$ & $\begin{array}{l}\text { Freedom; will; } \\
\text { originality; } \\
\text { ingenuity; } \\
\text { inspiration; } \\
\text { imagination }\end{array}$ & $\begin{array}{l}\text { Critical complex thinking; } \\
\text { creative capital; associative } \\
\text { thinking; acceptance of } \\
\text { conflict; analytical } \\
\text { problem-solving skills }\end{array}$ & $\begin{array}{l}\text { Dyer, Gregersen, and } \\
\text { Christensen (2011); } \\
\text { Ferrary and } \\
\text { Granovetter (2009); } \\
\text { Florida (2005) }\end{array}$ \\
\hline $\begin{array}{l}\text { 4. Lifelong and } \\
\text { collective learning } \\
\text { mindset }\end{array}$ & $\begin{array}{l}\text { Emphasis on lifelong learning } \\
\text { enables knowledge absorption } \\
\text { and transfer as a continuous } \\
\text { process of adaptation to } \\
\text { change }\end{array}$ & $\begin{array}{l}\text { To what extent is lifelong } \\
\text { learning rewarded? }\end{array}$ & $\begin{array}{l}\text { What kind of } \\
\text { knowledge prevails? } \\
\text { How is lifelong } \\
\text { learning stimulated? } \\
\text { How are learning } \\
\text { processes managed? }\end{array}$ & $\begin{array}{l}\text { Curiosity; will; } \\
\text { flexibility; } \\
\text { dedication; } \\
\text { motivation; }\end{array}$ & $\begin{array}{l}\text { Learning skills; self- } \\
\text { organization; time } \\
\text { management; cultural } \\
\text { capital }\end{array}$ & $\begin{array}{l}\text { Argote and Ingram, } \\
\text { (2000); Himanen } \\
(2001)\end{array}$ \\
\hline $\begin{array}{l}\text { 5. Risk acceptance } \\
\text { and tolerance of } \\
\text { failure }\end{array}$ & $\begin{array}{l}\text { Risk acceptance and tolerance of } \\
\text { failure facilitate } \\
\text { experimentation and learning } \\
\text { processes and increase the } \\
\text { chance of future success }\end{array}$ & $\begin{array}{l}\text { To what extent are risks } \\
\text { and failures tolerated? }\end{array}$ & $\begin{array}{l}\text { ¿What kind of risk is } \\
\text { tolerated? How is } \\
\text { failure dealt with? }\end{array}$ & Tolerance; curiosity & $\begin{array}{l}\text { Resilience; ability to take } \\
\text { calculated risks; flexibility; } \\
\text { experimentation; learning } \\
\text { capacity }\end{array}$ & $\begin{array}{l}\text { Hofstede (2011); } \\
\text { Jucevicius (2009); } \\
\text { Marcati, Guido, and } \\
\text { Peluso, (2008); Tellis, } \\
\text { Prabhu, and Chandy, } \\
\text { (2009) }\end{array}$ \\
\hline $\begin{array}{l}\text { 6. Entrepreneurial } \\
\text { spirit }\end{array}$ & $\begin{array}{l}\text { Entrepreneurial spirit, based on a } \\
\text { drive for achievement, vision } \\
\text { and passion, supplies the } \\
\text { necessary resources to start } \\
\text { new projects }\end{array}$ & $\begin{array}{l}\text { To what extent is } \\
\text { individual initiative } \\
\text { rewarded or } \\
\text { sanctioned? }\end{array}$ & $\begin{array}{l}\text { What kind of responses } \\
\text { are given to } \\
\text { individual or } \\
\text { collective initiatives? } \\
\text { How are they } \\
\text { rewarded? }\end{array}$ & $\begin{array}{l}\text { Passion; eagerness } \\
\text { for achievement; } \\
\text { future vision; } \\
\text { perseverance }\end{array}$ & $\begin{array}{l}\text { Leadership; self-confidence; } \\
\text { ability to mobilize } \\
\text { commitment; negotiation } \\
\text { skills; self-organization }\end{array}$ & $\begin{array}{l}\text { Acs (2006); Drucker } \\
\text { (2014); Hussler } \\
\text { (2004) }\end{array}$ \\
\hline
\end{tabular}


Dimension 5: Risk acceptance and tolerance of failure. This set of values and skills may facilitate experimentation and learning processes and increase the chance of future success. Societies with low uncertainty aversion are considered more innovative. Accordingly, firms that are able to learn from their failures may be more tolerant, deal better with uncertainties and develop skills about self-consciousness.

Dimension 6: Entrepreneurial spirit. Values of entrepreneurial spirit, based on orientation to achievement, self-motivation and persistence, are considered a mechanism to supply the resources needed to start new projects. Associated values and skills, also present in entrepreneurs, are the ability to undertake complex tasks involving different people and resources, because they are usually required to start a new business.

Not all six dimensions are necessarily present in all innovative firms. We assume that specific combinations of values and skills may deliver distinctive cultures of innovation. Columns 3 and 4 in Table 1 reflect the perspectives for the understanding of culture that are useful for empirical analysis. Both singular culture (etic) and plural cultures (emic) perspectives are considered (Jucevicius, 2010). The common research questions from both perspectives are specified for each dimension. When observing these dimensions, we can adopt an etic approach from a mainly external point of view (the main research questions are concerned with 'What', as stated in the corresponding column) or choose an emic perspective that pursues a more insider understanding of the cultural importance (the main questions are concerned with 'How' the cultural traits relate to innovation).

In our research, we consider each of the six dimensions in order to guide our observations and to explain the social and cultural mechanisms that make up the specific cultures of innovation of small firms. Also, we address the open innovation strategies that micro firms develop, according to their cognitive expertise and skills, and the relation with the prevailing cultural assets of their corporate cultures.

\section{Methodology}

\subsection{Data sources}

The methodological design follows a triangulation strategy that combines a survey of micro firms with qualitative interviews and case studies of selected firms. Each source is considered useful for observing relevant issues of the innovation process. The purpose of the representative survey is to depict the situation of micro firms in the Canary Islands ${ }^{2}$ in relation to innovation. In particular, the survey is used to identify potential innovators and to observe the innovation dynamics of the firms in terms of their capacities, interactions and beliefs. The open-ended interviews to owners of firms with an innovative profile have been used to observe the main characteristics of innovation processes, and also to identify dynamics, according to the role of cultural values. The purpose of the three case studies is to observe the detailed mechanisms of their innovation processes. The case studies are considered typical forms of innovation shaped by cultural elements.

\subsection{Survey}

This survey was part of a broader study on innovation dynamics of micro firms (1-9 employees) in the Canary Islands. The framework for the population of firms was the 
Table 2. Relationship between firms' innovativeness and cultural traits.

\begin{tabular}{llll}
\hline & Cultural influences on innovative behaviour & & $\begin{array}{c}\text { New product or service } \\
\text { development in the last 3 years }\end{array}$ \\
\hline $\begin{array}{l}\text { Beliefs and opinions } \\
\text { about innovation }\end{array}$ & Do you think that the lack of qualified human & Yes & $27.10 \%$ \\
& resources is a burden for innovation? & No & $20.10 \%$ \\
& Do you think that the lack of time is a burden for & Yes & $27.10 \%$ \\
innovation? & No & $20.30 \%$ \\
& Do you think that collaboration with research & Yes & $26.90 \%$ \\
& groups boosts innovation? & No & $19.60 \%$ \\
\hline
\end{tabular}

Note: The percentages shown in table 2 correspond to answers of firms with an active innovation profile ( $25.6 \%$ of the sample).

registry of firms of the regional government (official statistics do not collect data on micro firms). However, firms with fewer than 10 employees represent $95 \%$ of all firms in the region. A sample of 450 firms was designed and distributed according to strata composed by the business sector and the island location of the firm. Fieldwork was based on computer-assisted telephone interviews. The final sample resulted in a total of 434 firms (error of $4.6 \%$ for a $95 \%$ confidence level) ${ }^{3}$.

The findings of the survey help to identify the innovative profiles of micro firms. Only $25.6 \%$ of the sample (111 micro firms) has an active innovation profile; $56.2 \%$ can be considered as non-innovative firms, and $18.7 \%$ of firms have a profile of modest innovators. ${ }^{4}$ These results show the low innovation rate of micro firms in the region. The main determinants of the innovative profile are firms' human and social capital, their ability to absorb external knowledge, their values relating to innovation and the existence of stable interactions between companies, researchers and governments (González de la Fe, Hernández Hernández, \& Van Oostrom, 2012).

Regarding the relationship between firms' innovativeness and cultural traits, the outcome of the survey pinpointed a certain cultural influence. Table 2 shows that the lack of qualified human resources and time is appreciated to a greater extent by firms that have developed new products or services in the last three years than those who did not. Also, collaboration with research groups is considered important for innovation by a much larger portion of innovative firms (27\%) than by those who did not innovate (20\%). Some of these items can therefore be considered as proxies of the culture of innovation, since they represent cultural components of firms' innovativeness. However, we view them only as an explorative indicator for a possible cultural influence on firms' innovativeness, since the correlation is weak.

\subsection{Interviews}

The survey was used to identify knowledge intensive firms. Nine micro firms were selected from those with an active innovation profile ${ }^{5}$ and approached in order to explore social and cultural innovation dynamics. The selection was oriented by the well-known taxonomy of Asheim and Coenen (2005), which focuses on the knowledge bases of productive processes: analytical, synthetic and symbolic knowledge bases. This classification helps to establish distinct strategic research sites in order to observe social mechanisms. Open-ended interviews were conducted in order to examine similarities and differences in innovation processes, to study open innovation strategies and to observe entrepreneurs' perceptions and opinions. 
Table 3. Characteristics of the case studies.

\begin{tabular}{|c|c|c|c|}
\hline $\begin{array}{l}\text { Case studies/ } \\
\text { main features }\end{array}$ & Case 1 & Case 1 & Case 3 \\
\hline $\begin{array}{l}\text { Knowledge } \\
\text { base }\end{array}$ & Analytic & Synthetic & Symbolic \\
\hline Sector & Biotechnology & Engineering ICT & Videogames \\
\hline Founding year & 2010 & 1997 & 2011 \\
\hline Main activity & $\begin{array}{l}\text { Development of microbiological } \\
\text { molecules and vaccines for } \\
\text { allergic and asthma } \\
\text { pharmaceutics }\end{array}$ & $\begin{array}{l}\text { Consultancy and technological } \\
\text { development of } \\
\text { communication and satellite } \\
\text { systems }\end{array}$ & $\begin{array}{l}\text { Development of casual } \\
\text { videogames for mobile } \\
\text { phones and commercial } \\
\text { gaming apps }\end{array}$ \\
\hline Employees & 8 & 9 & 8 \\
\hline $\begin{array}{l}\text { International } \\
\text { activity }\end{array}$ & $\begin{array}{l}\text { Strong presence in the UK and } \\
\text { the U.S. through formal } \\
\text { collaboration with university } \\
\text { laboratories }\end{array}$ & $\begin{array}{l}\text { Inserted in collaborative } \\
\text { networks on the mainland } \\
\text { (Spain) and with a commercial } \\
\text { officer in London }\end{array}$ & $\begin{array}{l}\text { Inserted in virtual communities } \\
\text { (forums) on Internet; strong } \\
\text { presence and visibility on } \\
\text { social networks }\end{array}$ \\
\hline $\begin{array}{l}\text { Clients and } \\
\text { market }\end{array}$ & International pharmacy industry & $\begin{array}{l}\text { Local and national market for } \\
\text { consultancy; national and } \\
\text { international market (Central } \\
\text { and South America) for } \\
\text { satellite technology } \\
\text { development }\end{array}$ & $\begin{array}{l}\text { International virtual platforms } \\
\text { such as App Store and Google } \\
\text { Play for videogames; local } \\
\text { and national clients for } \\
\text { commercial gaming apps }\end{array}$ \\
\hline $\begin{array}{l}\text { Profile of the } \\
\text { entrepreneur } \\
\text { (s) }\end{array}$ & $\begin{array}{l}\text { The three founding partners } \\
\text { have PhDs and worked in the } \\
\text { international pharmaceutical } \\
\text { industry before creating their } \\
\text { firm }\end{array}$ & $\begin{array}{l}\text { The founding director is a high } \\
\text { profile engineer actively } \\
\text { involved in clusters and } \\
\text { professional associations }\end{array}$ & $\begin{array}{l}\text { The founding entrepreneur is a } \\
\text { self-made and self-instructed } \\
\text { artist who was employed in } \\
\text { an international animation } \\
\text { study before start up }\end{array}$ \\
\hline $\begin{array}{l}\text { Main } \\
\text { knowledge } \\
\text { providers }\end{array}$ & Internal knowledge production & $\begin{array}{l}\text { Universities, clients and other } \\
\text { firms }\end{array}$ & $\begin{array}{l}\text { Users' community and peers in } \\
\text { online forums }\end{array}$ \\
\hline
\end{tabular}

\subsection{Case studies}

The nine micro firms were further screened according to a set of qualitative criteria: (1) whether the firm was a reference in its sector in the region, ${ }^{6}(2)$ whether the firm had successful revenues and innovative products on the market and (3) whether the firm had been promoted by entrepreneurs with earlier business experience and possible failures. Three firms were selected for in-depth case studies. Although the three firms share a combination of different knowledge bases, each case is considered as a typical representative form of synthetic, analytic and symbolic knowledge: a biotechnology firm (analytic), an engineering telecommunication firm (synthetic) and a videogames company (symbolic). ${ }^{7}$ The characteristics of the three firms are included in Table 2 .

The case studies consisted of interviews with the managing owner or entrepreneur of the firms, a review of documentary evidence (brochures, webpages, firms' presence online and in specialized press) and external interviews with regional experts on innovation familiar with these firms (experts on innovation agencies and technology transfer offices). The interviews were semi-structured in order to obtain insights into specific mechanisms regarding the six dimensions in Table 1. The various interview rounds were designed according to the history of the firm and focused on any of the successful innovation endeavours. After coding and content analysis, the results were interpreted according to the main dimensions of the culture of innovation, in terms of homogeneity or specificity of cultural traits (Table 3 ). 


\section{Results and discussion}

\subsection{Social and cultural mechanisms for innovation and the firm's knowledge base}

The case studies show different aspects of the six dimensions of the culture of innovation in analytical, synthetic and symbolic knowledge-based firms. First, the findings evidence that some of the dimensions are present in all firms: 'openness to novelty' (dimension 1), 'acceptance of diversity' (dimension 3) and 'entrepreneurial spirit' (dimension 6). This suggests the presence of traits common to a culture of innovation. Second, the other dimensions show a variety of differences that lead to context-specific cultures of innovation. Specifically, the outcome regarding the plurality of innovation culture is reflected in the different presence of 'willingness to cooperate and share knowledge' (dimension 2); 'lifelong and collective learning mindset' (dimension 4) and 'risk tolerance' (dimension 5), as analysed below in each of the three case studies.

\subsubsection{Case study 1: Analytical knowledge-based firm}

The outcome of this case study shows that the firm develops an internally oriented culture of innovation with strong normative and formal features. Innovation processes lean on codified and universal expert knowledge, which is highly structured, documented and controlled, in close connection with scientific research procedures. For any important innovation, a significant investment in resources and time is required. This results in long-term product development (up to 10 years). The resulting innovation is considered expensive and of high value to the company. Accordingly, changes to business strategies are limited. The high cost of investment explains the firm's interest in protecting innovation by all possible means: intellectual property rights (IPR), confidentiality agreements, patenting, etc.

'Willingness to cooperate and share knowledge' (dimension 2) in this case is rather scarce. When it occurs, it follows strict protocols and non-disclosure agreements with third parties. 'Lifelong and collective learning mind' (dimension 4) is highly present, although it is very specialized and restricted internally to the firm's team members. As for 'risk tolerance' (dimension 5), this type of firm cannot afford to risk any possible leak of valuable information, due to high costs and the long-term development of the new product. The following comment clearly reflects this situation:

We have very specialised knowledge and we know that nobody works with techniques like ours in our field, and we want to keep it that way. We cannot afford for any information, however unimportant it may seem, to leave the company. (CEO biotechnology firm)

Consequently, collaborative relationships are formal, selective and regulated. Outsourcing to companies is preferred over collaboration. Outsourcing is carried out for non-sensitive tasks, usually different from the core business, or for strategic market issues such as international protection of IPR, which is crucial for small technology-based enterprises (Hossain, 2015). These cases reflect a common situation in biotechnology firms, for which incentives to associate with companies of the same sector are scarce (García Carpintero, Albert-Martínez, Granadino, \& Plaza, 2014). Therefore, intellectual capital and patenting of valuable knowledge are far more important than social capital.

As for human capital, different profiles, albeit in the same field of specialization, are complementary for this firm. The organizational structure is hierarchical, with vertical 
relationships between the project manager and the rest of the team. Learning processes are somewhat individual and in line with the features of innovation processes: structured, documented and controlled. High specialization raises the barriers for learning, which depends on expertise. Proximity to other partners and knowledge providers does not play an important role. Interactive learning is not so important in this case, because an important part of the knowledge base is accessible through global scientific networks and publications.

\subsubsection{Case study 2: Synthetic knowledge-based firm}

In this engineering firm, the culture of innovation, unlike the first case, is oriented towards external networks and collaboration. Innovation processes are both structured and open, depending on cooperative interactions with business and technological partners. Adjustment to change tends to depend on product development. The terms for product development are between two and three years. Sensitive intellectual and industrial property is protected, but information and common expertise is shared in relevant professional communities. This is useful for obtaining new knowledge but also for reputation and recognition from peers (Himanen, 2001).

'Willingness to cooperate and share knowledge' (dimension 2) for this kind of firm is not only necessary for innovation processes, but also for access to global markets in order to obtain sufficient credibility with bigger international stakeholders. 'Lifelong and collective learning mindset' (dimension 4) is based on coded and tacit knowledge and learning processes that transcend the firm's boundaries. Accordingly, 'risk tolerance' (dimension 5) is less calculated than in the first case. The firm is mostly concerned about core developments, which are protected with formal collaboration agreements and IPR, alongside open relations with external networks. Social networks and collaboration are based on trust and mutual benefit in order to gain credibility and critical mass in global markets. The following statement reflects this situation:

For a small company, entering global markets (without the correct partners) is not reliable, even with the right experience and competitive technologies, simply because it lacks financial muscle and critical mass to dedicate to the conquest of new markets. (CEO high-tech telecom firm)

The human capital of the firm comprises heterogeneous profiles. The firm frequently incorporates external collaborators from other firms in its projects. Both coded and tacit knowledge are exchanged through interactive learning processes between internal and external team members. Multiple interactions give rise to new shared routines, as a result of learning through practice and use. Therefore, the firm, together with partners, develops a culture of innovation that supports interactive learning with other firms, scientific staff at research centres and clients. The work of this firm is more dependent on the specific context, and proximity gains importance because of the need to access expert partners and collaborators. In sum, for this firm, social capital is as important as intellectual capital.

\subsubsection{Case study 3: Symbolic knowledge-based firm}

This videogames firm tends to develop a community-driven culture of innovation. User experience (UX) and interactive open collaborative processes are vital for new product development, which takes a few months to be market-ready. Knowledge and development are shared in open-access forums, which allows the community to grow and expand by 
creatively recombining existing knowledge, sometimes following hacker ethics (Himanen, 2001). Intellectual property rights are not important. Instead, creativity, co-creation and context-specific learning through trial and error are preeminent.

'Willingness to cooperate and share knowledge' (dimension 2) is therefore very important. It allows firms to access and reuse existing knowledge for their new product developments. For this reason, 'longlife and collective learning mindset' (dimension 4) is easily assumed by team members who socialize in open professional communities. 'Risk tolerance' (dimension 5) is especially present because of the benefits of co-creation with users and wider creative communities through knowledge sharing in open environments.

Interactions are very important for peer-learning processes in open virtual professional communities. For this firm, social and creative capital are the main assets. Product development team profiles are very diverse and include designers, artists, developers, marketers, etc. The organizational structure is horizontal and based on distributed team leadership (Spillane, 2012), whose unity and motivation is considered a key aspect. The following comment reflects the collaborating and collective culture of the firm:

Here the process of creativity is a group dynamic. Everything is done as a team. From the first moment, music, art, everything, is part of a collective process of creative product development. (CEO videogame firm)

In this context, proximity is vital for firm innovation. Territorial proximity is required for both learning and collaborative processes. In sum, this firm reflects an important contextspecific trait for its innovation processes.

\subsection{A plurality of innovation cultures}

The above results reveal a plurality of specific cultures of innovation. Some universal traits are also identified, as we highlighted in the previous section. The differences stress context-specific aspects such as the firm's cognitive expertise, the sector, the territory and particular institutional arrangements regarding core innovation processes: collaboration and learning processes. A culture of innovation understood as the combination of traits related to learning and collaboration, as suggested by Jucevicius (2007), therefore seems relevant and appropriate. Moreover, the other dimensions of the culture of innovation, as defined here, are similar in all three cases, although some differences are evident. For example, 'openness to novelty' (dimension 1) shows differences due to product development terms in all three cases: from very long-term (10 years) in the biotechnology firm (analytic) to very short-term (few months) in the videogames firm (symbolic).

Rather than a single culture in innovative micro firms, it seems more appropriate to speak about plural cultures of innovation with some common traits. On the one hand, the common traits seem to be present in all innovative organizations. 'Openness to novelty' (dimension 1), 'acceptance of diversity and critical thinking' (dimension 3) and 'entrepreneurial spirit' (dimension 6) are observed in all case studies and confirmed by similar observations from interviews. This finding is also consistent with specialized empirical research that considers these traits as part of the general modernization process of organizations, with wider implications in the population of regions and countries (Wieland, 2006). On the other hand, core innovation issues, such as learning and collaboration processes, highlight differences between resulting cultures of innovation 
Table 4. Cultures of innovation informed by main dimensions.

\begin{tabular}{|c|c|c|c|}
\hline Case studies/dimensions & $\begin{array}{c}\text { case 1: Analytic } \\
\text { knowledge-based firm }\end{array}$ & $\begin{array}{c}\text { Case 2: Synthetic } \\
\text { knowledge-based firm }\end{array}$ & $\begin{array}{l}\text { Case 3: Symbolic knowledge- } \\
\text { based firm }\end{array}$ \\
\hline \multirow[t]{2}{*}{ 1. Openness to change } & $\begin{array}{l}\text { Importance of state-of-the- } \\
\text { art }\end{array}$ & $\begin{array}{l}\text { Constant adaptation to } \\
\text { change }\end{array}$ & Continuous adaptation \\
\hline & $\begin{array}{l}\text { Few new products because } \\
\text { of long development } \\
\text { terms (up to } 10 \text { years) }\end{array}$ & $\begin{array}{l}\text { Anticipating to change } \\
\text { within } 3 \text { years for new } \\
\text { product development }\end{array}$ & $\begin{array}{l}\text { Frequent new product } \\
\text { launches that need few } \\
\text { months to deliver }\end{array}$ \\
\hline \multirow[t]{3}{*}{$\begin{array}{l}\text { 2. Willingness to cooperate } \\
\text { and share knowledge }\end{array}$} & $\begin{array}{l}\text { High costs of innovation } \\
\text { limits knowledge sharing }\end{array}$ & $\begin{array}{l}\text { Knowledge and information } \\
\text { is shared with certain } \\
\text { limits }\end{array}$ & $\begin{array}{l}\text { Open knowledge sharing with } \\
\text { users in communities } \\
\text { without limits }\end{array}$ \\
\hline & $\begin{array}{l}\text { Formal and normative } \\
\text { collaboration }\end{array}$ & $\begin{array}{l}\text { Frequent collaborations also } \\
\text { for gaining credibility }\end{array}$ & Informal collaboration \\
\hline & $\begin{array}{l}\text { High impact of intellectual } \\
\text { capital vs. low impact of } \\
\text { social capital }\end{array}$ & $\begin{array}{l}\text { High impact of social and } \\
\text { intellectual capital }\end{array}$ & $\begin{array}{l}\text { High impact of social and } \\
\text { creative capital }\end{array}$ \\
\hline \multirow[t]{2}{*}{$\begin{array}{l}\text { 3. Acceptance of diversity } \\
\text { and critical, divergent } \\
\text { and creative thinking }\end{array}$} & $\begin{array}{l}\text { Diversity limited to the } \\
\text { boundaries of the team }\end{array}$ & $\begin{array}{l}\text { Diversity both inside and } \\
\text { outside the team }\end{array}$ & $\begin{array}{l}\text { Wide diversity inside and } \\
\text { outside the team: } \\
\text { multidisciplinary }\end{array}$ \\
\hline & $\begin{array}{l}\text { Homogeneous profiles due } \\
\text { to high specialization }\end{array}$ & $\begin{array}{l}\text { Heterogeneous profiles in } \\
\text { multidisciplinary teams }\end{array}$ & Stress on unity of team \\
\hline \multirow[t]{4}{*}{$\begin{array}{l}\text { 4. Lifelong and collective } \\
\text { learning mindset }\end{array}$} & $\begin{array}{l}\text { Very structured, organized } \\
\text { and documented } \\
\text { process }\end{array}$ & $\begin{array}{l}\text { Interactive learning } \\
\text { processes }\end{array}$ & $\begin{array}{l}\text { Interactive learning processes } \\
\text { through community and } \\
\text { users }\end{array}$ \\
\hline & High access barriers & $\begin{array}{l}\text { Emphasis on problem } \\
\text { solving applying } \\
\text { knowledge from different } \\
\text { sources }\end{array}$ & $\begin{array}{l}\text { Open culture with free access } \\
\text { to knowledge that is } \\
\text { recombined }\end{array}$ \\
\hline & Emphasis on the individual & Emphasis on the network & Emphasis on the team \\
\hline & $\begin{array}{l}\text { Low importance of } \\
\text { proximity, global } \\
\text { knowledge networks }\end{array}$ & $\begin{array}{l}\text { Importance of proximity and } \\
\text { network learning }\end{array}$ & $\begin{array}{l}\text { Importance on learning } \\
\text { through failure and self- } \\
\text { taught learning, very } \\
\text { context-specific }\end{array}$ \\
\hline 5. Risk tolerance & $\begin{array}{l}\text { Very calculated risk, no } \\
\text { tolerance }\end{array}$ & Calculated risk, tolerance & High risk tolerance \\
\hline 6. Entrepreneurial spirit & No differences observed & No differences observed & No differences observed \\
\hline Cultures of innovation & $\begin{array}{l}\text { Internally oriented with } \\
\text { strong normative and } \\
\text { formal features }\end{array}$ & $\begin{array}{l}\text { External oriented towards } \\
\text { networks and } \\
\text { collaboration }\end{array}$ & $\begin{array}{l}\text { Community driven by users' } \\
\text { experience }\end{array}$ \\
\hline
\end{tabular}

regarding internal and external features, and the relevance of social, intellectual and creative capital in each case.

Finally, the role of social capital in each of these cultures is clearly different, as reflected in micro firms' open innovation strategies. Different types of capital are involved (social, intellectual and creative) in each case study. Social capital seems to be important for firms with a synthetic and symbolic knowledge base, but not so much for firms with an analytical knowledge base, where intellectual capital is a fundamental and constituent asset. Intellectual and social capital are equally important for these firms. In contrast, for the symbolic knowledge-based firm, both creative capital and social capital are decisive for interactions with the community. Table 4 shows an overview of the specific cultures of innovation as discussed in this section.

\subsection{Cultures of innovation and firms' open innovation strategies}

Our observations point to two key findings in terms of the links of these results with firms' open innovation strategies: on the one hand, the existence of closed innovation strategies 
in analytical knowledge-based micro firms that foster an internally oriented culture of innovation with strong normative and formal features. The high cost of innovation limits openness. Collaboration with external partners only exists through formal confidentiality and IPR agreements. Open innovation appears to be more useful for small companies in their marketing phases than in other phases, such as $\mathrm{R} \& \mathrm{D}$ activities, which are more appropriate for large firms. In these cases, small firms would benefit from patenting, despite the inconvenience of associated costs (Hossain, 2015).

On the other hand, an open innovation strategy is clearly present in the other two types of cultures of innovation, albeit in different ways. The external network and collaborationoriented culture that defines synthetic knowledge-based firms relies on both formal and informal institutions. Here, protection is required for certain phases of (technological) development, in order to avoid placing new product developments at risk. But this culture also enhances knowledge sharing through participation in open online communities and professional workshops. A more balanced open innovation strategy helps these firms to interact in global markets, and to combine IPR and open knowledge at different stages of their innovation processes. So, synthetic knowledge-based firms typically follow an open innovation approach (Chesbrough, 2003), although they would benefit from incorporating cultural observations in micro firms.

In symbolic knowledge-based firms, with a typical community-driven culture of innovation, open innovation seems to be a common strategy for connecting with users and learning through their experience. No protection other than the registration of trademarks is considered. Creativity and recombination of existing knowledge imply the existence of multidisciplinary teams and their interactions with communities. A wide open innovation strategy thus explains the culture of innovation of this kind of firm.

Finally, it is worthwhile mentioning that innovative micro firms, in contrast with larger firms, cope with a bounded capacity for knowledge selection and absorption, which limits their open innovation potential. Maintaining intensive external networks demands resources and the valuable time of qualified and creative human resources, which are very scarce in micro firms. Also, the protection of intellectual property or the regulation of shared knowledge, when required, involves costs and specialized management, hard to get for micro firms.

\section{Conclusions and implications}

In this article, observations of Spanish innovative micro firms from a peripheral region have been used in order to identify the social and cultural mechanisms that shape their innovation processes. The research strategy is based on a cross-fertilization of theoretical approaches and the triangulation of different data sources. Mainstream innovation literature has been combined with contributions from cultural and institutional sociology. The empirical work has benefited from the triangulation of information, with a combination of different data sources that facilitate the observation of the richness and complexity of innovation dynamics in micro firms, especially the functioning of cultural factors.

The contributions of this paper are threefold. First, a conceptual contribution is made through the development of an operational definition of the notion of culture of innovation and its main dimensions. Second, the empirical findings contribute to the 
discussion on homogeneity versus plurality of cultures of innovation. Third, the results facilitate the observation of cultural and social mechanisms that shape the innovation dynamics in micro firms, and the diversity of open innovation strategies. The outcomes suggest, in general, that the debate on open innovation strategies could benefit with the consideration of an operational cultural dimension, as provided here, in future research.

The results show that not all dimensions of the culture of innovation have the same relevance for micro firms' innovation strategies. The dimensions with greater explanatory capacity are those associated with the fundamental processes of innovation: collaboration and learning. Both processes involve myriad interactions that depend on the openness versus closeness of the collaboration and learning interactions between actors, the degree of formal versus informal protection and sharing, and the importance of creative versus structured procedures, amongst others. The values and skills associated with these fundamental processes of collaboration and learning form a plurality of cultures of innovation. Future research should address strategies in order to provide a right balance between learning and cooperation and ways to implement them.

The outcomes reveal the presence of several traits in all innovative companies: 'openness to novelty' (dimension 1), 'acceptance of diversity' (dimension 3) and 'entrepreneurial spirit' (dimension 6). This points towards the universal aspects of a culture of innovation. The combination of other traits forms specific cultural profiles of innovation: 'willingness to cooperate and share knowledge' (dimension 2); 'lifelong and collective learning mindset' (dimension 4) and 'risk tolerance' (dimension 5). This explains the existence of context-specific cultures of innovation in a plural and specific sense.

In summary, the first case study of an analytical knowledge-based firm reveals an internal oriented, normative and formal culture of innovation. The second case study of a synthetic knowledge-based firm shows an externally oriented network culture of innovation. The third case study of a symbolic knowledge-based firm displays a communitydriven culture of innovation.

The plurality of cultures of innovation that emerges throughout the case studies can be seen as models or types of culture. As such, the results have implications for regions that wish to promote a culture of innovation. At firm level, strategies and practices could be directed towards increasing firms' capacity for collaboration and learning as fundamental processes for innovation. The findings of this research are also useful for policymakers seeking to design sectorial policy instruments involving, for example, upgrading micro firms towards more robust, bigger firms that can cope more easily with open innovation challenges. Intellectual property assessments or facilitating productive partnerships between small firms and government-funded industry or research centres could be provided. The outcomes of this study also suggest parallels with other peripheral regions with similar socioeconomic traits. In this sense, the findings provide useful insights for policymakers concerned with promoting a culture of innovation and with analysing the cultural dimensions of regional innovation performance and capacities or a culture of innovation amongst local small firms.

\section{Notes}

1. This table is based on a review of mainstream literature and earlier reviews on the connections between culture, innovation and firm performance (Bueschgens, Bausch, \& Balkin, 
2013; Crossan \& Apaydin, 2010; Hogan \& Coote, 2014; McLean, 2005; van der Panne et al., 2003). Most earlier reviews concern the organizational level, with some exceptions that focus on the macro (regional) level (Trippl \& Toedtling, 2008) or several levels of analysis (Castro \& García, 2014).

2. The Canary Islands are Spain's outermost region and are located in the Atlantic Ocean, close to the northwest coast of Africa and Morocco. They mainly have a service economy, which is highly dependent on tourism (30\% of the region's GDP). The region has one of the lowest rates of innovation performance in the European Union (Annoni, Dijkstra, \& Gargano, 2017).

3. The survey covered the seven Canary Islands. The questionnaire was structured in five dimensions: (1) general characteristics of the company; (2) firms' innovation activities and attitudes; (3) use of ICT; (4) assessment of the regional context; and (5) entrepreneurs' personal traits. The methodology and the findings of this survey are found in González de la Fe et al. (2012). One of the main goals of the survey was to identify the subsector of micro firms carrying out activities in the knowledge economy, mainly in high-tech and intensive knowledge sectors.

4. Innovativeness of micro firms is measured according to the frequency and intensity of innovation activities: 'Non innovative' firms are those which almost never introduce innovative products or services in the market. 'Moderate innovators' are those with an average of three innovative activities in the last three years. 'Active innovators' are firms that have implemented at least four innovative products or services in the market in the last three years. Over $70 \%$ of this group has done so more than once.

5. An overwhelming part of active innovators belongs to the service sector, especially tourism and the more traditional commercial sectors.

6. We checked for visibility and reputation in the media, and whether these firms had received awards or public recognition.

7. In analytic knowledge base firms, codified knowledge prevails and innovations are produced by creating new knowledge through scientific research and formal models, often in collaboration with research centres. In synthetic knowledge, base firms tacit knowledge prevails and innovations arise through a novel combination of existing knowledge and applied problemsolving engineering processes. In symbolic knowledge, base firms' innovation occurs by a recombination of existing knowledge in new ways, relying on tacit and practical crafts and skills (Asheim \& Coenen, 2005).

\section{Disclosure statement}

No potential conflict of interest was reported by the authors.

\section{ORCID}

Madelon van Oostrom (D) http://orcid.org/0000-0001-6505-3101

\section{References}

Acs, Z. (2006). How is entrepreneurship good for economic growth? Innovations: Technology, Governance, Globalization, 1(1), 97-107. doi:10.1162/itgg.2006.1.1.97

Amin, A., \& Thrift, N. (1995). Globalisation, institutional thickness and the local economy. Managing Cities: The New Urban Context, 12, 91-108.

Annoni, P., Dijkstra, L., \& Gargano, N. (2017). The EU regional competitiveness index 2016.

Argote, L., \& Ingram, P. (2000). Knowledge transfer: A basis for competitive advantage in firms. Organizational Behavior and Human Decision Processes, 82(1), 150-169. doi:10.1006/obhd. 2000.2893 
Asheim, B., \& Coenen, L. (2005). Knowledge bases and regional innovation systems: Comparing Nordic clusters. Research Policy, 34(8), 1173-1190. doi:10.1016/j.respol.2005.03.013

Asheim, B., \& Isaksen, A. (2002). Regional innovation systems: The integration of local 'sticky' and global 'ubiquitous' knowledge. The Journal of Technology Transfer, 27(1), 77-86.

Benito Hernández, S., Platero Jaime, M., \& Rodríguez Duarte, A. (2012). Factores determinantes de la innovación en las microempresas españolas: La importancia de los factores internos/ Determinants of innovation in Spanish micro-enterprises: The importance of internal factors. Universia Business Review, 33, 104.

Bessant, J., \& Tidd, J. (2007). Innovation and entrepreneurship. Chichester: John Wiley \& Sons.

Bosma, N., van Praag, M., Thurik, R., \& de Wit, G. (2004). The value of human and social capital investments for the business performance of startups. Small Business Economics, 23(3), 227-236. doi:10.1023/B:SBEJ.0000032032.21192.72

Bourdieu, P. (1986). The forms of capital. In N. W. Biggart (Ed.), Readings in Economic Sociology (pp. 280-291). Oxford: Blackwell.

Bueschgens, T., Bausch, A., \& Balkin, D. B. (2013). Organizational culture and innovation: A metaanalytic review. Journal of Product Innovation Management, 30(4), 763-781. doi:10.1111/jpim. 12021

Casper, S., \& Van Waarden, F. (2005). Innovation and institutions. Cheltenham: Edward Elgar.

Castro, E., \& García, A. (2014). La relación entre cultura e innovación : tres ámbitos de análisis. In B. Laspra \& E. Muñoz (Eds.), Culturas científicas e innovadoras. Progreso Social (pp. 237-254). Eudeba.

Chesbrough, H. (2003). Open innovation: The new imperative for creating and profiting from technology. Boston, MA: Harvard Business Press.

Chesbrough, H. (2012). Open innovation: Where we've been and where we're going. ResearchTechnology Management, 55(4), 20-27. doi:10.5437/08956308X5504085

Cohen, W. M., \& Levinthal, D. A. (1990). Absorptive capacity: A new perspective on learning and innovation. Administrative Science Quarterly, 35(1), 128-152. doi:10.2307/2393553

Cooke, P., Gomez Uranga, M., \& Etxebarria, G. (1997). Regional innovation systems: Institutional and organisational dimensions. Research Policy, 26(4-5), 475-491. doi:10.1016/S0048-7333 (97)00025-5

Crossan, M. M., \& Apaydin, M. (2010). A multi-dimensional framework of organizational innovation: A systematic review of the literature. Journal of Management Studies, 47(6), 11541191. doi:10.1111/j.1467-6486.2009.00880.x

DiMaggio, P. (1997). Culture and cognition. Annual Review of Sociology, 23(263), 25.

DiMaggio, P., \& Powell, W. (1983). The iron cage revisited: Institutional isomorphism and collective rationality in organizational fields. American Sociological Review, 48(2), 147-160. doi:10. 2307/2095101

Drucker, P. (2014). Innovation and entrepreneurship. Routledge.

Dyer, J., Gregersen, H., \& Christensen, C. (2011). The innovator's DNA: Mastering the five skills of disruptive innovators. Boston, MA: Harvard Business Press.

Edquist, C. (2001). The systems of innovation approach and innovation policy: An account of the state of the art. 1-24.

Edquist, C. (2005). Systems of innovation: Perspectives and challenges. In The Oxford handbook of innovation (pp. 181-208). Oxford: Oxford University Press.

Fagerberg, J., \& Verspagen, B. (2009). Innovation studies - The emerging structure of a new scientific field. Research Policy, 38(2), 218-233. doi:10.1016/j.respol.2008.12.006

Fernández-Esquinas, M. (2012). Hacia un programa de investigación en sociología de la innovación. Arbor. Revista de Pensamiento, Ciencia y Cultura, 188(753), 5-18.

Fernández-Esquinas, M., \& Pinto, H. (2014). The role of universities in urban regeneration: Reframing the analytical approach. European Planning Studies, 22(7), 1462-1483. doi:10.1080/ 09654313.2013.791967

Fernández-Esquinas, M., Pinto, H., Yruela, M. P., \& Pereira, T. S. (2016). Tracing the flows of knowledge transfer: Latent dimensions and determinants of university-industry interactions. Technological Forecasting and Social Change, 113(part), 266-279. doi:10.1016/j.techfore.2015. 07.013 
Ferrary, M., \& Granovetter, M. (2009). The role of venture capital firms in Silicon Valley's complex innovation network. Economy and Society, 38(2), 326-359. doi:10.1080/03085140902786827

Florida, R. (2005). The flight of the creative class. New York, NY: Harper Business.

Freel, M. S. (2005). Patterns of innovation and skills in small firms. Technovation, 25(2), 123-134. doi:10.1016/S0166-4972(03)00082-8

García Carpintero, E., Albert-Martínez, A., Granadino, B., \& Plaza, L. M. (2014). Análisis de la colaboración entre las empresas biotecnológicas españolas con actividades de I+D y el sistema público de I+D. Revista española de Documentación Científica, 37(2), e041. doi:10.3989/redc. 2014.2.1106

Godin, B. (2008). Innovation: The history of a category. Project on the Intellectual History of Innovation Working, (1), pp. 1-67.

González de la Fe, T., Hernández Hernández, N., \& Van Oostrom, M. (2012). Innovación, cultura y tamaño: la microempresa en una región ultraperiférica. Arbor, 188(753), 113-134. doi:10.3989/ arbor.2012.753n1008

Granovetter, M. (1985). Economic action and social structure: The problem of embeddedness. American Journal of Sociology, 91(3), 481-510. doi:10.1086/228311

Granovetter, M. S. (1973). The strenght of weak ties. American Journal of Sociology, 78, 1360-1380. doi: $10.1086 / 225469$

Gray, C. (2006). Absorptive capacity, knowledge management and innovation in entrepreneurial small firms. International Journal of Entrepreneurial Behavior \& Research, 12(6), 345-360. doi:10.1108/13552550610710144

Himanen, P. (2001). La ética del hacker y el espíritu de la era de la información. Barcelona: Ediciones Destino.

von Hippel, E. (2005). Democratizing innovation: The evolving phenomenon of user innovation. Journal f\{ü\}r Betriebswirtschaft, 55(1), 63-78. doi:10.1007/s11301-004-0002-8

Hofstede, G. (1980). Culture's consequences: International differences in work-related values. Beverly Hills, CA: Sage.

Hofstede, G. (2011). Dimensionalizing cultures: The Hofstede model in context, Online Readings in Psychology and Culture, 2(1), 1-26. doi:10.9707/2307-0919.1014

Hogan, S. J., \& Coote, L. V. (2014). Organizational culture, innovation, and performance: A test of Schein's model. Journal of Business Research, 67(8), 1609-1621. doi:10.1016/j.jbusres.2013.09. 007

Hossain, M. (2015). A review of literature on open innovation in small and medium-sized enterprises. Journal of Global Entrepreneurship Research, 5(1). doi:10.1186/s40497-015-0022-y

Hussler, C. (2004). Culture and knowledge spillovers in Europe: New perspectives for innovation and convergence policies? Economics of Innovation and New Technology, 13(6), 523-541. doi:10.1080/1043859042000234302

James, A. (2005). Demystifying the role of culture in innovative regional economies. Regional Studies, 39(9), 1197-1216. doi:10.1080/00343400500389968

Jaruzelski, B., Loehr, J., \& Holman, R. (2011). Why culture is key. The global innovation 1000, Strategy+Business, Winter 2011(65).

Jucevicius, G. (2007). Innovation culture: The contestable universality of the concept. Social Sciences, 58(4), 7-19.

Jucevicius, G. (2009). The innovation culture in modern Lithuanian organizations: Values, attitudes and practices, Social Sciences, 63(1), 38-45.

Jucevicius, G. (2010). Culture vs. Cultures of innovation: Conceptual framework and parameters for assessment. ICICKM proceedings of the 7th internationl conference on intellectual capital, knowledge management and organizational learning, Hong Kong.

Lundvall, B. A., \& Borrás, S. (1997). The globalising learning economy: implications for innovation policy. Malerba, F. (2005). Sectoral systems of innovation: A framework for linking innovation to the knowledge base, structure and dynamics of sectors. Economics of Innovation and New Technology, 14(1-2), 63-82. doi:10.1080/1043859042000228688 
Manley, K. (2003). Frameworks for understanding interactive innovation processes. The International Journal of Entrepreneurship and Innovation, 4(1), 25-36. doi:10.5367/ 000000003101299375

Marcati, A., Guido, G., \& Peluso, A. M. (2008). The role of SME entrepreneurs' innovativeness and personality in the adoption of innovations. Research Policy, 37(9), 1579-1590. doi:10.1016/j. respol.2008.06.004

McLean, L. D. (2005). Organizational culture's influence on creativity and innovation: A review of the literature and implications for human resource development. Advances in Developing Human Resources, 7(2), 226-246. doi:10.1177/1523422305274528

Nelson, R., \& Winter, S. (1982). An evolutionary theory on economic change. Cambridge, MA: The Belknap Press of Harvard University Press.

van der Panne, G., van Beers, C., \& Kleinknecht, A. (2003). Success and failure of innovation: A literature review. International Journal of Innovation Management, 07(3), 309-338. doi:10. 1142/S1363919603000830

Pilon, S., \& DeBresson, C. (2003). Local culture and regional innovative networks: New hypotheses and some propositions.

Portes, A. (2013). Sociología económica. Una investigación sistemática. Madrid: Centro de Investigaciones Sociológicas (CIS).

Ruef, M. (2002). Strong ties, weak ties and islands: Structural and cultural predictors of organizational innovation. Industrial and Corporate Change, 11(3), 427-449. doi:10.1093/icc/11.3.427

Sackmann, S. (1997). Cultural complexity in organizations: Inherent contrasts and contradictions. London: Sage.

Schwartz, S. H. (1994). Are there universal aspects in the structure and content of human values? Journal of Social Issues, 50(4), 19-45. doi:10.1111/j.1540-4560.1994.tb01196.x

Spillane, J. P. (2012). Distributed leadership. John Wiley \& Sons.

Swidler, A. (1986). Culture in action: Symbols and strategies. American Sociological Review, 51(2), 273. doi:10.2307/2095521

Tellis, G. J., Prabhu, J. C., \& Chandy, R. K. (2009). Radical innovation across nations: The preeminence of corporate culture, Journal of Marketing, 73(1), 3-23. doi:10.1509/jmkg.73.1.3

Tether, B. S., Mina, A., Consoli, D., \& Gagliaardi, D. (2005). A literature review on skills and innovation. How does successful innovation impact on the demand for skills and how do skills drive innovation? Policy, (September) 1-124.

Trippl, M., \& Toedtling, F. (2008). Regional innovation cultures.

Vossen, R. W. (1998). Relative strengths and weaknesses of small firms in innovation. International Small Business Journal, 16(3), 88-94. doi:10.1177/0266242698163005

Werker, C., Ooms, W., \& Caniëls, M. (2014). The role of personal proximity in collaborations : The Case of Dutch nanotechnology. DRUID society conference 2014 CBS copenhague, June 16-18.

Wieland, T. (2006). Innovation culture, technology policy and The uses of history. International ProACT conference. Innovation pressure, 15-17 March 2006, Tampere, Finland.

Zelizer, V. (2010). Economic lives: How culture shapes the economy. Princeton, NJ: Princeton University Press. 